\title{
Pre-Service Teachers' Evaluation on their Student Internship Program
}

\author{
Darin Jan Tindowen, Jennifer Bangi and Cirilo Parallag Jr. \\ University of Saint Louis \\ Tuguegarao City, Philippines
}

\begin{abstract}
This study was conducted to evaluate the implementation of the student internship program of the University of Saint Louis, specifically in the Teacher Education Program. The respondents of the study were the 62 Pre-Service Teachers who had their internship last SY 2018-2019. The results reveal that the student internship program of the Teacher Education Department is effective since it is responsive to the needs of the current industries and at the same time, effective in helping students develop both hard and soft skills needed in their chosen profession. Furthermore, pre-service teachers have positive experiences in the conduct of their student internship program.
\end{abstract}

Keywords: Student internship Program, Teacher Education, Evaluation, Pre-service Teachers.

\section{Introduction}

Education is considered as the bedrock to development as it contributes to the growth of every nation by improving the skills and productive capacity of workers. With this, Higher Education institutions (HEIs) in the Philippines continuously produce graduates in the different fields since they play a vital role in the development of the knowledge-based economy where innovation, research and knowledge are considered vital that will result to sustainable development (Ortiga, 2018; Shahabadi, Kimiaei, \& Afzali, 2018; De Guzman, Edaño, \& Umayam, 2017). However, it is a challenge for HEIs in the Philippines to produce highly skilled graduates who can respond to the needs of the globalized world (Gonzalez-Roma, Gamboa, \& Peiro, 2018; Pinto \& Ramalheira, 2017; Tindowen, Bassig, \& Cagurangan, 2017).

With globalization and the challenge of HEIs in producing graduates, employability then is one of the significant goals among Higher Education Institutions (Payne, 2018; McGee, 2019) especially in developing countries such as the Philippines (Borja, 2018; Aguila, De Castro, Dotong, \& Laguador 2016). Employability refers to the capability of graduates to attain and to effectively employ their knowledge, competencies, skills, and desirable attitudes within a 
specific setting to self-sufficiently fulfill their potential by maintaining their work and employment (Romgen, Scoupe \& Beausaert, 2019; Boden \& Nedeva, 2010). Hence, it is essential that every graduate must see to it that adequate skills and competencies be developed. However, a substantial number of studies had revealed that there is an increasingly wide gap between the competencies and skills of graduates and the requirements and skills required in work industries (Li, Harris, \& Sloane, 2018; Mok \& Qian, 2018; Balcar, Simek, \& Filipova, 2018). With this scenario, graduates' skills and competencies should be given important consideration. Schultz (2008) stipulated that employability of graduates also involves skills in both the hard (academic and technical) and soft (personality traits and habits) skill areas.

To realize this goal, HEIs in the Philippines are coming up with mechanisms and initiatives to ensure that their graduates are prepared to face the professional world. Among these mechanisms that are being employed by HEIs is the student internship program. Since learning takes place in varied forms and systems, student internship program has been considered as a vital part of the higher education curriculum since it connects the gap between theory and practice. Furthermore, this also serves as an application of the classroom education into the industry setting providing adequate and practical learning experiences among students (Loscalzo \& Giannini, 2019; Wikan \& Klein, 2017; Batool, Ellahi, \& Masood, 2012). A substantial number of studies stressed how vital is internship program among students before their college graduation. Student internship program creates an avenue for students to learn more about their profession and also generating values and substance in their skills (Hussein \& La Lopa, 2018; Sojkin \& Michalak, 2018; Ylagan, 2013; Edward Beck \& Halim, 2008). More importantly, internship program for students serves as an instrument for increasing employability after their graduation. It is also used to increase the integration of students to the labor market by many different countries. Hence, student-internship program is an instrument to prepare students as a potential labour force for employment.

The University of Saint Louis, a Catholic Higher Education Institution of learning in Northern Philippines, adheres to its mission of preparing its students to become active and competent missionary graduates across its programs through providing quality and effective student internship programs across all academic programs, such as Teacher Education. Teacher Education Institutions (TEIs) are institutionalized to offer quality and holistic pre-service education among prospective teachers (Mangila, 2018). Student internship program for pre-service teachers is one of the most important and critical academic formation in the teacher education curriculum as it prepares them to become effective and qualified teachers in the future (Salviana, Muslem, \& Daud, 2018; Scales, Wolsey, Lenski, Smetana, Yder, \& Young, 2018; Ulla, 2016). With its current setting, student internship program in the Teacher Education is a one-year (twosemester) program to prepare pre-service teachers in the actual teaching world. They are employed for one semester in USL-Basic Education Department and one semester in a public school. 
In this context, it is then important that student internship in the Teacher Education program be evaluated. Literatures are faithful in stressing the need for student evaluation on their internship program to improve the delivery of education (Mangila, 2018; Ulla, 2016). In this way, pre-service teachers reflect on major issues and problems based on their experiences which can provide useful feedback about not only the quality of their teacher education program (Mehdinezhad, 2008). This study then is conducted to evaluate the student internship Program of Teacher Education department.

\section{Research Objective}

This study was conducted to evaluate the implementation of the student internship program of the University of Saint Louis, specifically in the Teacher Education department.

\section{Conceptual Framework}

This study was anchored on the Commission on Higher Education Memorandum Order (CMO) No. 104 series of 2017 which is entitled the Revised Guidelines for Student Internship Program in the Philippines (SIPP) for All Programs. Internship or Student internship program is meant to offer students with opportunities and avenues to supplement their formal learning formation with practical knowledge, competencies and attitudes and to provide industrybased experience in recognized Host Training Establishment (HTE). Specifically, the OJT/Internship program has the following objectives:

a. Strengthen the implementation of the local internship through the collaborative effort of the academe-industry linkage among HEIs and partner institution/establishment.

b. Establish the harmonious collaboration/linkages between higher education institutions (HEIs) and the Host Training Establishments (HTEs) for effective implementation of the program to support the educational environment of the student interns.

c. Train student interns under actual workplace conditions.

Furthermore, the student internship program for pre-service teachers is a joint responsibility of the Teacher Education Institution (TEIs) and its Cooperating Schools or Host Training Establishments (HTEs). These two major stakeholders are responsible for the successful implementation of internship program among pre-service teachers. They have major and specific responsibilities and duties to do in order to attain the major objectives of student internship program. Hence, student internship program evaluation should be focused on the three major aspects: (1) institutional evaluation assessing the responsibilities and functions of the Teacher Education Institution (TEI) on the student internship program of pre-service teachers, (2) company evaluation assessing the responsibilities and functions Cooperating Schools or Host Training Establishments (HTEs) on the student internship program of pre-service teachers, and (3) effectiveness of the student internship program. 


\section{Methods}

This study utilized a descriptive method of research. The study was conducted at the University of Saint Louis, Tuguegarao City, Philippines. The respondents of the survey were Pre-Service Teachers who had their internship program last SY 2018-2019.

Table 1: Profile of the Respondents

\begin{tabular}{ccc}
\hline Field of Specialization & $\begin{array}{c}\text { Frequency } \\
(\mathbf{N = 6 2 )}\end{array}$ & $\begin{array}{c}\text { Percentage } \\
(\mathbf{\% = 1 0 0 . 0 0 )}\end{array}$ \\
\hline English & 20 & 30.77 \\
\hline Mathematics & 8 & 12.90 \\
\hline General Science & 6 & 9.68 \\
\hline Social Science & 7 & 11.29 \\
\hline $\begin{array}{c}\text { Music, Arts, Physical Education } \\
\text { and Health }\end{array}$ & 12 & 19.35 \\
\hline Elementary Education & 9 & 14.52 \\
\hline Total & 62 & 100.00 \\
\hline
\end{tabular}

\section{Research Instrument}

This study utilized a quantitative questionnaire to evaluate the implementation of the student internship program by the institution and partner agencies. The items were based on the Commission on Higher Education Memorandum Order (CMO) No. 104 series of 2017 which is entitled the Revised Guidelines for Student Internship Program in the Philippines (SIPP). The said tool consists of 19 items which is divided into three categories which are institutional evaluation (9 items), company evaluation (7 items), and effectiveness of the Student internship program (3 items) with the following scale:

$\begin{array}{ll}\text { Rating } & \text { Qualitative Description } \\ 4 & \text { Strongly Agree } \\ 3 & \text { Agree } \\ 2 & \text { Disagree } \\ 1 & \text { Strongly Disagree } \\ 0 & \text { Not Applicable }\end{array}$

Furthermore, the questionnaire, before its administration to target respondents, was checked and validated by the members of the University Research and Development Center, Academic Deans, and the Vice President for Academics. In addition, reliability test was also conducted to determine its reliability and validity. Results revealed a .90 reliability value. Hence, the questionnaire is valid and reliable to the target respondents.

Meanwhile, an open-ended question was also used to describe the experiences of pre-service teachers on their internship program.

Ethical considerations were observed, such as keeping the confidentiality and anonymity of the respondents, avoiding biases, especially in the analysis of data and proper authorities and communication is also ensured in the study. 


\section{Data Analysis}

Descriptive statistics were used to analyze the data. Specifically, it utilized the following statistical tools:

Frequency and Percentage were used to describe the profile of the respondents as to their field of specialization.

Mean was used to assess the student internship program of pre-service teachers along with institutional evaluation, company evaluation and program effectiveness using the following scale:

\begin{tabular}{ccc}
\hline Scale & \multicolumn{2}{c}{ Qualitative Description } \\
\cline { 2 - 3 } & $\begin{array}{c}\text { Institutional and Company } \\
\text { Evaluation }\end{array}$ & Program Effectiveness \\
\hline $3.50-4.00$ & Fully Implemented (FI) & Very Effective (VE) \\
\hline $2.50-3.49$ & Implemented (I) & Effective (E) \\
\hline $1.50-2.49$ & Partially Implemented (PI) & Slightly Effective (SE) \\
\hline $1.00-1.49$ & Not Implemented (NI) & Not Effective (NE) \\
\hline
\end{tabular}

Finally, thematic analysis was used to describe the experiences of pre-service teachers on their internship program.

\section{Results and Discussion}

Table 2. Assessment of Pre-service Teachers on their Internship Program along Institutional Evaluation

\begin{tabular}{|c|c|c|c|c|c|c|c|}
\hline \multirow{2}{*}{ Institutional Evaluation } & \multicolumn{5}{|c|}{ \% Responses } & \multirow{2}{*}{ Mean } & \multirow{2}{*}{ QD } \\
\hline & 4 & 3 & 2 & 1 & 0 & & \\
\hline $\begin{array}{l}\text { Conduct of pre-deployment and } \\
\text { orientation with regards to the } \\
\text { Student internship program, } \\
\text { including its requirements and } \\
\text { expectations. }\end{array}$ & 38 & 24 & 0 & 0 & 0 & 3.91 & FI \\
\hline $\begin{array}{l}\text { Provision of needed services and } \\
\text { assistance such as recommendations } \\
\text { in finding the company }\end{array}$ & 35 & 26 & 1 & 0 & 0 & 3.55 & FI \\
\hline $\begin{array}{l}\text { Coordination with the industry in the } \\
\text { implementation of internship. }\end{array}$ & 38 & 24 & 0 & 0 & 0 & 3.50 & FI \\
\hline $\begin{array}{l}\text { Forging of Memorandum of } \\
\text { Agreement (MOA) between USL and } \\
\text { the company/agency }\end{array}$ & 29 & 28 & 2 & 3 & 0 & 3.55 & FI \\
\hline $\begin{array}{l}\text { Academic preparations of Students to } \\
\text { undertake company assignments and } \\
\text { its challenges. }\end{array}$ & 35 & 27 & 0 & 0 & 0 & 3.47 & I \\
\hline $\begin{array}{l}\text { Regular monitoring of the } \\
\text { School/Department through the } \\
\text { student internship Coordinator with } \\
\text { regards to students' progress in the } \\
\text { company }\end{array}$ & 29 & 32 & 1 & 0 & 0 & 3.47 & I \\
\hline
\end{tabular}




\begin{tabular}{|l|c|c|c|c|c|c|c|}
\hline $\begin{array}{l}\text { Giving of timely feedbacks to pre- } \\
\text { service teachers }\end{array}$ & 39 & 21 & 2 & 0 & 0 & 3.70 & FI \\
\hline $\begin{array}{l}\text { Conduct of an student internship } \\
\text { program evaluation upon completion } \\
\text { of students in their internship } \\
\text { program. }\end{array}$ & 37 & 21 & 3 & 0 & 1 & 3.70 & FI \\
\hline $\begin{array}{l}\text { Giving of results of school assessment } \\
\text { to pre-service teachers }\end{array}$ & 31 & 27 & 2 & 0 & 2 & 3.66 & FI \\
\hline TOTAL/CATEGORY MEAN & $\mathbf{3 5}$ & $\mathbf{2 6}$ & $\mathbf{1}$ & $\mathbf{0}$ & $\mathbf{0}$ & $\mathbf{3 . 6 1}$ & FI \\
\hline
\end{tabular}

Table 2 presents the evaluation of Teacher Education students on the student internship program of their department. It is shown from the table that preservice teachers believed that the different requirements of their student internship programs were fully implemented. The findings mean that the University of Saint Louis through its Teacher Education Department sees to it that all the provisions concerning the conduct of student internship program in different primary education institutions in the City of Tuguegarao. Specifically, pre-service teachers stressed that the implementation of an orientation prior to their immersion in their specific workplace was fully implemented. This part of the student internship programs plays a very crucial role in the success of the said program since this part will give students the knowledge and understanding not only about the program itself but also about other dimensions such as the workplace environment, work expectations and deliverables, ethical practices and behaviour in the workplace, and other essential matters. Orientation programs, especially for internships and wok immersions of students, are intended to assist students make a successful transition to the work environment from the classroom and formal education setting. This activity sets the tone for student expectations and begins the process of integrating students into the work and professional culture. Successful student internship orientation may lead to successful internship experience among students (Rothman, 2007).

Meanwhile, another notable highlight of the results of the present study is on the importance of giving feedback and assessments to pre-service students. The Teacher Education Area through the different Supervising instructors always ensure that feed backing is done regularly, through one-on-one and class feedbacking. Feedback on teaching performance among pre-service teachers is a significant part of the learning process, allowing pre-service teachers to identify their strengths and most especially their weaknesses in teaching methods and pedagogies (Coco, 2000). Furthermore, recent studies revealed that students' success in doing an internship could be seen if proper and regular feedbacking had been conducted to monitor students' development and progress (Wright, Miller, Dawes, \& Wrigley, 2018; Eyler \& Giles, 2014; Knouse \& Fontenot, 2008). Furthermore, studies also show that feedback improves student's confidence, self-awareness and enthusiasm, which will prepare them in the real-work setting (Ditzel, Hogarth, \& Lesa, 2017; Rothman, 2007).

Furthermore, two provisions about the conduct of student internship program of the Teacher Education are implemented as assessed by pre-service teachers. 
These include academic preparations of students to undertake company assignments and its challenges and regular supervision and monitoring of the School/Department through the internship Coordinator about students' progress in the company. This kind of practice may address the problem with the mismatch of skills provided by the academe be used in the industry. In this kind of training, sectors and partner agencies may collaborate with the academe on what skills and programs the school and department may introduce and implement to further enhance the hard skills of students (Patacsil \& Tablatin, 2017; Belwal, Priyadarshi, \& Al Fazari, 2017; An \& Mauhay, 2016).

Table 3. Assessment of Pre-service Teachers on their Internship Program along Company Evaluation

\begin{tabular}{|c|c|c|c|c|c|c|c|}
\hline \multirow{2}{*}{ Company Evaluation } & \multicolumn{5}{|c|}{$\%$ Responses } & \multirow{2}{*}{ Mean } & \multirow{2}{*}{ QD } \\
\hline & 4 & 3 & 2 & 1 & 0 & & \\
\hline $\begin{array}{l}\text { Appropriateness of the kind of } \\
\text { training needed and required }\end{array}$ & 43 & 19 & 0 & 0 & 0 & 3.50 & FI \\
\hline $\begin{array}{l}\text { Designed of the training to meet the } \\
\text { course objectives and expected } \\
\text { competencies }\end{array}$ & 43 & 19 & 0 & 0 & 0 & 3.52 & FI \\
\hline $\begin{array}{l}\text { Coordination with USL, through the } \\
\text { student internship Coordinator, in } \\
\text { the implementation and conduct of } \\
\text { the internship. }\end{array}$ & 32 & 29 & 1 & 0 & 0 & 3.57 & FI \\
\hline $\begin{array}{l}\text { Company Treatment to pre-service } \\
\text { teachers }\end{array}$ & 38 & 23 & 1 & 0 & 0 & 3.80 & FI \\
\hline $\begin{array}{l}\text { Facilitation of the training, including } \\
\text { the provision of the necessary } \\
\text { resources/facilities needed to achieve } \\
\text { the objectives of the Student } \\
\text { internship program }\end{array}$ & 29 & 31 & 2 & 0 & 0 & 3.61 & FI \\
\hline $\begin{array}{l}\text { Assigned a supervisor to oversee } \\
\text { students' work }\end{array}$ & 42 & 19 & 1 & 0 & 0 & 3.64 & FI \\
\hline $\begin{array}{l}\text { Supervision of the } \\
\text { through } \\
\text { consultation or advise }\end{array}$ & 33 & 29 & 0 & 0 & 0 & 3.53 & FI \\
\hline TOTAL/CATEGORY MEAN & 37 & 24 & 1 & 0 & 0 & 3.60 & FI \\
\hline
\end{tabular}

Table 3 presents the assessment of Teacher Education students on their student internship program along company evaluation. It is seen on the table that all provisions concerning the responsibilities and duties of companies and partner agencies of USL are all fully implemented. It means that USL's partner agencies provide students with practical and real-life work experience and atmosphere, and exposure to various teaching and learning methodologies and approaches. Among the different provisions, it is gleaned in the table that pre-service teachers observed positive company treatment towards them. It means that Host Department of Education (DepEd) schools offer a favourable and nonthreatening atmosphere for pre-service teachers which made them appreciate their profession better. It is also revealed in the table that the host HTE also assigned a supervisor to oversee students' work. In the realm of USL, pre-service teachers were assigned with cooperating teachers in line with their field of 
specialization who will serve as their supervisors. In this scenario, students were provided with hands-on opportunities to know their strengths and weaknesses in the teaching and learning process through giving of assistance, constructive criticisms, feed backing, and also to serve as a role model in the chosen field. This is cognizant with previous studies stressing that pre-service teachers should be well-monitored, supervised, and guided by their cooperating teachers for them to become prepared (Borja, 2018; Mangila, 2018; Rothman, 2007).

Finally, facilities and resources that are needed the student internship program of pre-service teachers are also being observed by HTEs as assessed by preservice teachers. It means that Department of Education (DepEd) schools are also responsive to the needs of its interns and pre-service teachers by providing training and professional growth activities and by providing facilities and materials for holistic teaching experience. Allowing students to apply what they learned from their formal schooling through their Student internship program will lead to acquisition of important work values and competencies important to achieve the ultimate goal of producing effective and competent professionals in this competitive world (Robinson, 2018; An \& Mauhay, 2016).

Table 4: Effectiveness of the Student internship program of Pre-Service Teachers

\begin{tabular}{|c|c|c|c|c|c|c|c|}
\hline \multirow{2}{*}{ Program Effectiveness } & \multicolumn{5}{|c|}{ \% Responses } & \multirow{2}{*}{ Mean } & \multirow{2}{*}{ QD } \\
\hline & 4 & 3 & 2 & 1 & 0 & & \\
\hline $\begin{array}{l}\text { Exposure to real world problems and } \\
\text { practice }\end{array}$ & 49 & 13 & 0 & 0 & 0 & 3.61 & VE \\
\hline $\begin{array}{l}\text { Development of workplace values } \\
\text { and ethics }\end{array}$ & 53 & 9 & 0 & 0 & 0 & 3.73 & VE \\
\hline $\begin{array}{l}\text { Improvement of personal skills and } \\
\text { human relations. }\end{array}$ & 57 & 5 & 0 & 0 & 0 & 3.77 & $\mathrm{VE}$ \\
\hline TOTAL/CATEGORY MEAN & 53 & 9 & 0 & 0 & 0 & 3.70 & $\mathrm{VE}$ \\
\hline
\end{tabular}

Table 4 presents the effectiveness of the student internship program to preservice teachers. It is shown from the table that the Student internship program is very useful for pre-service teachers to experience the real-teaching practice and to develop both hard and soft skills needed in the chosen profession of students. Experiences in real-work setting give pre-serve teachers exposure to future workplaces and opportunities to explore how they were positioned in terms of graduate knowledge, skills, and proficiencies (Boyd, Lembke, \& Scott, 2019). It is then inferred from the results that student internship program is a vital part of teacher education's curriculum as it helps pre-service teachers the required competencies and skills through hands-on training as it exposes them to the different and varied learning styles and work environment and consequently, they learned. It also allows students to become familiar with the different pedagogies and strategies and techniques that they will use in their future work endeavors. With the student internship program, students were able to apply the knowledge, demonstrate required competencies, enrich desirable and positive attitude and sharpen the character of the students towards a holistic appreciation of the actual workplace (De Chavez, et al., 2016). Clear enough, the Student internship program of the university significantly 
contributes to the development of skills, personal qualities and competencies needed by teacher education graduates.

\section{Experiences of Students Regarding their Internship Program}

Theme 1. Positive and Healthy Working Environment

The major theme that is revealed from the responses of students with regards to their internship is that their assigned workplace promotes a healthy environment that makes students feel that they are part of the institution. Some of the responses of the respondents are as follows:

O29 - I am happy with my internship because of the positive environment that I felt in the workplace that would make you think your belongingness and their respectful treatment as an intern. I learned a lot from my supervisors. They also guided me to become professional someday.

O14 - Teachers and the school principal are well accommodating and kind. They gave me different tasks that are related to my profession.

Theme 2. Exposure to Real-Life Workplace Environment and Practice

Indeed, the student internship program of the Teacher Education Department is responsive to the needs of students since it is also found out that students are given opportunities to apply relevant knowledge and skills acquired from formal education to actual work setting provided. Some of the responses of the respondents are as follows:

O13 - My internship experience trained me on how to become a professional teacher soon.

O12 -All my expectations were attained. I experienced to become a teacher for almost five months. Now, I believe I am ready to face the professional world of teaching.

O18 - My internship experience was beautiful. I learned how to apply the different things that I learned in different ways.

Theme 3. Relationship with Cooperating Teachers and Supervisors

Another theme that was found out in the study is the relationship of students to their supervisor. Previous studies reveal that one of the major concerns and issues that arise in the duration of student internship is pre-service teachers and cooperating teachers and supervisor relationship (Rose, 2018; Newman, Rose, \& Teo, 2016). In the present study, it was found out that pre-service teachers experienced this kind of situations both in positive and negative ways. Some of the responses of the respondents are as follows: 
O8 - My internship was wonderful. I learned a lot from my cooperating teacher. She really became my model and guide for my internship to be successful.

O23 - Our cooperating teacher was very strict in the sense that she cannot monitor us well. Furthermore, my internship was almost done, yet she doesn't still know my name.

Theme 4. Discipline Related Work

One important issue that is revealed in this study is the appropriateness and applicability of the different assignments and functions of pre-service teachers in the workplace. It has been a significant issue that students experienced from their respective agency or organization (Jacobs \& Jaseem Bu-Rahmah, 2012; Shoho, Barnett, \& Martinez, 2012). This issue is also revealed in this study. Some of the responses of the respondents are as follows:

O22 - Tasks should be aligned to our field, which should be focused on teaching and learning however, there are times that we were doing unnecessary tasks that are not aligned to our field.

O34 - The Department must see to it that the assigned office of the student trainee is aligned to his/her program.

\section{Conclusions}

The main purpose of the present study is to evaluate the internship-program of pre-service teachers. Three major conclusions and implications were derived based on the major results of the study.

First, student internship program of pre-service teachers is considered as the best avenue for students to apply the theoretical and conceptual knowledge that they learned in the classroom into their actual teaching. The findings of the study is consistent with the findings of previous studies stressing that the preservice teachers' internship program is the best way for students to be trained and exposed to the real classroom teaching for them to become prepared and qualified teachers in the country (Ulla, 2016; Batool, Ellahi, \& Masood. 2012).

Second, it can be gleaned from the results that positive experiences of pre-service teachers on their internship program is due to the high compliance of Teacher Education Institution and Host Training Establishment on the different provisions stipulated in the Commission on Higher Education Memorandum Order (CMO) No. 104 series of 2017.

And finally, despite the positive experiences and learning gained by pre-service teachers, still there are challenges and issues that they experienced during their internship especially on the kind of work that they must engage in. Hence, regular evaluation and feed backing must be conducted by pre-service teachers, Teacher Education Institutions and Host Training Establishments to fill the gaps regarding the issues encountered by students. 
In general, it can be concluded that the internship program of pre-service teachers is useful since it is responsive to the needs of the current industries and at the same time, effective in helping students develop both hard skills and soft skills needed in their chosen profession.

\section{Recommendations}

The Teacher Education Department should sustain the different activities and initiatives before the implementation of the Student internship program for the students to orient themselves with expectations and their work responsibilities. In-service trainings and professional growth activities must also be sustained by both the academe and partner industries.

The curriculum and course syllabus for the Teacher Education should be reviewed regularly to match the skills needed by the industry and organization. The curriculum should be designed to prepare the graduates to become competent and active professionals in their future work endeavors.

Teacher Education Department may also look into possibilities of forging linkages for possible student internship program with industries both in national and international settings. Furthermore, the department may consider the development of institutional policies and guidelines regarding Student internship program or the development of an internship manual that may serve as the student term of reference.

\section{References}

Aguila, G. M., De Castro, E. L., Dotong, C. I., \& Laguador, J. M. (2016). Employability of computer engineering graduates from 2013 to 2015 in one private higher education institution in the Philippines. Asia Pacific Journal of Education, Arts and Sciences, 3(3), 48-54.

An, I. L., \& Mauhay, R. C. A. (2016). Interns' Feedback on Industry Partners: Inputs for an Enhanced Internship Program. Asia Pacific Journal of Education, Arts and Sciences, 3(2), 74-81.

Balcar, J., Šimek, M., \& Filipová, L. (2018). Soft skills of Czech graduates. Review of Economic Perspectives, 18(1), 45-60. doi:10.2478/revecp-2018-0003.

Batool, Z., Ellahi, N., \& Masood, A. (2012). National internship programme and its evaluation: A case study of Punjab region. Academic Research International, 2(2), $562-570$

Belwal, R., Priyadarshi, P., \& Al Fazari, M. H. (2017). Graduate attributes and employability skills: Graduates' perspectives on employers' expectations in Oman. International Journal of Educational Management, 31(6), 814-827.

Boden, R., \& Nedeva, M. (2010). Employing discourse: universities and graduate 'employability.' Journal of Education Policy, 25(1), 37-54. doi:10.1080/02680930903349489

Borja, R. E. (2018). Honing the 21st century characteristics of lecturers in the faculty of education for effective job performance. African Educational Research Journal, 6(3), 160-164.

Boyd, W., Lembke, C., \& Scott, A. (2019). The Impact of an Immersion Programme in Cambodia for Australian Pre-Service Teachers. Journal of International and Comparative Education, 8(1), 1-15. 
Coco, M. (2000). Internships: A try before you buy arrangement. SAM Advanced Management Journal, 65(2), 41-47.

De Guzman, M. F. D., Edaño, D. C., \& Umayan, Z. D. (2017). Understanding the Essence of the Outcomes-Based Education (OBE) and Knowledge of its Implementation in a Technological University in the Philippines. Asia Pacific Journal of Multidisciplinary Research, 5(4), 64-71.

Ditzel, L. M., Hogarth, K., \& Lesa, R. (2017). Immersive learning in nursing education: Results of a study. Journal of Nursing Education and Practice, 7(5), 120-130. doi:10.5430/jnep.v7n5p120

Edward Beck, J., \& Halim, H. (2008). Undergraduate internships in accounting: What and how do Singapore interns learn from experience?. Accounting Education: An International Journal, 17(2), 151-172. doi:10.1080/09639280701220277

Eyler, J., \& Giles Jr, D. (2014). The importance of program quality in service-learning. In S. Billig \& Waterman, A. (Eds). Service-learning (pp. 75-94). New York City, USA: Routledge.

González-Romá, V., Gamboa, J. P., \& Peiró, J. M. (2018). University graduates' employability, employment status, and job quality. Journal of Career Development, 45(2), 132-149. doi:10.1177/0894845316671607

Hussien, F. M., \& La Lopa, M. (2018). The determinants of student satisfaction with internship programs in the hospitality industry: A case study in the USA. Journal of Human Resources in Hospitality \& Tourism, 17(4), 502-527. doi:10.1080/15332845.2018.1486600

Jacobs, R. L., \& Jaseem Bu-Rahmah, M. (2012). Developing employee expertise through structured on-the-job training (S-OJT): an introduction to this training approach and the KNPC experience. Industrial and Commercial Training, 44(2), 75-84. doi:10.1108/00197851211202902

Knouse, S. B., \& Fontenot, G. (2008). Benefits of the business college internship: A research review. Journal of Employment Counseling, 45(2), 61-66. doi:10.1002/j.2161-1920.2008.tb00045.x

Li, I. W., Harris, M., \& Sloane, P. J. (2018). Vertical, horizontal and residual skills mismatch in the Australian graduate labour market. Economic Record, 94(306), 301-315. doi:10.1111/1475-4932.12413

Loscalzo, Y., \& Giannini, M. (2019). Study engagement in Italian university students: a confirmatory factor analysis of the Utrecht Work Engagement Scale-Student version. Social Indicators Research, 142(2), 845-854.

Mangila, B. B. (2018). Assessment of pre-service teachers on the practice teaching program: Inputs for program enhancement. Asia Pacific Journal of Education, Arts and Sciences, 5(3), 50-58.

McGee, I. E. (2019). Developing Mentor Teachers to Support Student Teacher Candidates. SRATE Journal, 28(1), 23-30.

Mehdinezhad, V. (2008). Evaluation of teacher education programs by students and graduates. (Unpublished doctoral dissertation). Finland, University of Turku.

Mok, K. H., \& Qian, J. (2018). Massification of higher education and youth transition: skills mismatch, informal sector jobs and implications for China. Journal of Education and Work, 31(4), 339-352. doi:10.1080/13639080.2018.1479838

Newman, A., Rose, P. S., \& Teo, S. T. (2016). The role of participative leadership and trust-based mechanisms in eliciting intern performance: Evidence from China. Human Resource Management, 55(1), 53-67. doi:10.1002/hrm.21660

Ortiga, Y. Y. (2018). Constructing a global education hub: the unlikely case of Manila. Discourse: Studies in the Cultural Politics of Education, 39(5), 767-781.

Patacsil, F. F., \& Tablatin, C. L. S. (2017). Exploring the importance of soft and hard skills as perceived by IT internship students and industry: A gap analysis. Journal of 
Technology and Science Education, 7(3), 347-368. doi:10.1080/01596306.2018.1448703

Payne, A. (2018). Assessing post-secondary graduates' soft skills, job search and employment outcomes (Unpublished master's thesis). University of Guelph, Ontario, Canada.

Pinto, L. H., \& Ramalheira, D. C. (2017). Perceived employability of business graduates: The effect of academic performance and extracurricular activities. Journal of Vocational Behavior, 99(1), 165-178. doi:10.1016/j.jvb.2017.01.005

Robinson, E. L. (2018). Immersion Learning in Social Work Education: A Pedagogical Tool for Enriching Knowledge and Practice Skills among BSW Students. Journal of Teaching in Social Work, 38(5), 536-550. doi:10.1080/08841233.2018.1516712

Römgens, I., Scoupe, R., \& Beausaert, S. (2019). Unravelling the concept of employability, bringing together research on employability in higher education and the workplace. Studies in Higher Education, doi:10.1080/03075079.2019.1623770.

Rose, P. S. (2018). The intern to employee career transition: An outsiders perception of insider status. Journal of Career Development, 45(6), 566-579. doi: $10.1177 / 0894845317725192$

Rothman, M. (2007). Lessons learned: Advice to employers from interns. Journal of Education for Business, 82(3), 140-144. doi:10.3200/JOEB.82.3.140-144

Salviana, S., Muslem, A., \& Daud, B. (2018). English Student Teachers' Constraints During Their Teaching Internship Programs with the English Departmnet of FKIP at UNSYIAH in Aceh. English Education Journal, 9(3), 466-489.

Scales, R. Q., Wolsey, T. D., Lenski, S., Smetana, L., Yoder, K. K., Dobler, E., ... \& Young, J. R. (2018). Are we preparing or training teachers? Developing professional judgment in and beyond teacher preparation programs. Journal of Teacher Education, 69(1), 7-21. doi:10.1177/0022487117702584.

Shahabadi, A., Kimiaei, F., \& Afzali, M. A. (2018). The evaluation of impacts of knowledge-based economy factors on the improvement of total factor productivity (a comparative study of emerging and G7 economies). Journal of the Knowledge Economy, 9(3), 896-907. doi:10.1007/s13132-016-0379-3

Shoho, A. R., Barnett, B. G., \& Martinez, P. (2012). Enhancing" OJT" Internships with Interactive Coaching. Planning and Changing, 43(1), 161-182.

Sojkin, B., \& Michalak, S. (2018). Student as a Beneficiary of Internship Programs Funded by the European Union. Marketing of Scientific and Research Organizations, 30(4), 91-114. doi:10.14611/minib.30.12.2018.15

Tindowen, D. J. C., Bassig, J. M., \& Cagurangan, J. A. (2017). Twenty-First-Century skills of alternative learning system learners. SAGE Open, 7(3). doi: $10.1177 / 2158244017726116$

Ulla, M. B. (2016). Pre-service teacher training programs in the Philippines: The studentteacher practicum teaching experience. EFL Journal, 1(3), 235-250. doi:10.21462/eflj.v1i3.23

Wikan, G., \& Klein, J. (2017). Can International Practicum Foster Intercultural Competence Among Student Teachers?. Journal of the European Teacher Education Network, 12, 95-104.

Wright, N., Miller, E., Dawes, L., \& Wrigley, C. (2018). Beyond 'chalk and talk': educator perspectives on design immersion programs for rural and regional schools. International Journal of Technology and Design Education, 1-31. doi:10.1007/s10798-018-9487-7.

Ylagan, A. P. (2013). Intensifying the Student internship program of the College of Business Administration, Lyceum of the Philippines University-Batangas. EInternational Scientific Research Journal, 5(1), 220-220. 